\title{
Conventional method and microwave drying kinetics of Laurus nobilis leaves: effects on phenolic compounds and antioxidant activity
}

\section{Cinética da secagem convencional e por micro-ondas de folhas de Laurus nobilis: efeitos sobre os compostos fenólicos e a atividade antioxidante}

\author{
Yazid Khaled Khodja1, Farid Dahmoune ${ }^{2}$, Mostapha Bachir bey ${ }^{3 *}$ (D), Khodir Madani², \\ Bachra Khettal ${ }^{1}$ \\ ${ }^{1}$ Université de Bejaia, Faculté des Sciences de la Nature et de la Vie, Laboratoire de Biotechnologies Végétales et \\ Ethnobotanique, Bejaia, Algeria \\ ${ }^{2}$ Laboratoire de Biomathématiques, Faculté des Sciences de la Nature et de la Vie, Biophysique, Biochimie et \\ Scientométrie, Bejaia, Algeria \\ ${ }^{3}$ Université de Bejaia, Faculté des Sciences de la Nature et de la Vie, Département des Sciences Alimentaires, \\ Laboratoire de Biochimie Appliquée, Bejaia, Algeria
}

*Corresponding Author: Mostapha Bachir bey, Université de Bejaia, Faculté des Sciences de la Nature et de la Vie, Département des Sciences Alimentaires, Laboratoire de Biochimie Appliquée, 06000 Bejaia, Algeria.

e-mail: bachirbeymustapha@gmail.com

Cite as: Khaled Khodja, Y., Dahmoune, F., Bachir bey, M., Madani, K., \& Khettal, B. (2020). Conventional method and microwave drying kinetics of Laurus nobilis leaves: effects on phenolic compounds and antioxidant activity. Brazilian Journal of Food Technology, 23, e2019214. https://doi.org/10.1590/1981-6723.21419.

\begin{abstract}
Laurus nobilis constitutes one of the usually studied Mediterranean trees due to its therapeutic effects, nutritional properties, and ornamental use. In the current investigation, a comparative study was conducted between two types of drying methods, a microwave-assisted drying (MWD) (from 180 to $900 \mathrm{~W}$ ) and a conventional method (open-air and oven-drying using temperatures from $40^{\circ} \mathrm{C}$ to $120^{\circ} \mathrm{C}$ ). Drying kinetics were carried out as a function of moisture content according to time. Total Phenolic Content (TPC) as well as reducing power of obtained products were determined. Kinetic results showed that the time required for dried bay leaves became shorter as temperature and microwave power increased; drying with the microwave was much more efficient than conventional methods (open-air and oven-drying). Antioxidants of the Laurus nobilis leaves were better conserved using open-air and microwave drying. Our results underlined a significant correlation between TPC and reducing power. Microwave drying using $300 \mathrm{~W}$ during $130 \mathrm{~s}$ was the most efficient combination that provided dried bay leaves with the highest content of phenolic compounds and antioxidant activity.
\end{abstract}

Keywords: Bay leaf; Open-air drying; Oven drying; Microwave drying; Phenolic compounds; Antioxidant capacity. 


\section{Resumo}

O loureiro, Laurus nobilis, constitui uma das árvores mediterrânicas geralmente estudadas devido aos seus efeitos terapêuticos, propriedades nutricionais e uso ornamental. Na atual investigação, realizou-se um estudo comparativo entre dois tipos de métodos de secagem, uma secagem assistida por micro-ondas (de 180 a $900 \mathrm{~W}$ ) e um método convencional (secagem ao ar e em forno usando temperaturas de $40^{\circ} \mathrm{C}$ a $120^{\circ} \mathrm{C}$ ). Estudou-se a cinética de secagem determinando o teor de umidade em função do tempo. Determinou-se também o teor em fenóis totais (TTF), bem como o poder redutor dos produtos obtidos. Os resultados cinéticos mostraram que o tempo necessário para a secagem das folhas de louro diminui à medida que a temperatura e a potência do micro-ondas aumentam; secar com o micro-ondas é muito mais eficiente do que os métodos convencionais (ao ar e em forno). As propriedades antioxidantes das folhas de Laurus nobilis mantiveram-se melhor quando se usou a secagem ao ar e por micro-ondas. Os nossos resultados sublinharam uma correlação significativa entre o TTF e o poder redutor. As condições mais eficientes de secagem que permitiram obter folhas de louro secas com o maior conteúdo de compostos fenólicos e a melhor atividade antioxidante consistiram na secagem por micro-ondas usando $300 \mathrm{~W}$ durante 130 segundos.

Palavras-chave: Folha de louro; Secagem ao ar livre; Secagem em forno; Secagem por Microondas; Compostos fenólicos; Capacidade antioxidante.

\section{Introduction}

The bay (Laurus nobilis L., Lauraceae family) is a largely studied medicinal plant regarding its phytochemical constituents (Chahal et al., 2017; Caputo et al., 2017) and therapeutic virtues such as treatment of several neurological, dermatological, and urological disorders as well as gastrointestinal issues like epigastric bloating, impaired digestion, flatulence, and eructation (Fidan et al., 2019; Batool et al., 2020).

Drying constitutes one of the oldest methods used by humans for food preservation, and also taking a prominent place in modern food processing (Maroulis \& Saravacos, 2003; Li et al., 2010). The procedure of drying consists of moisture reduction to a level that permits safe storage for an extended period. Furthermore, this method allows a substantial reduction in volume and weight too, minimizing packaging material, storage space, and transportation costs. The growing demand for shelf-stable and high-quality dried products requires design, simulation, and optimization for the drying process (Di Scala \& Crapiste, 2008). In addition, conventional drying involves exposing processed food to elevated temperatures and prolonged treatment periods, leading to aroma modifications, color changes, and nutrients loss of the treated material (Ozkan et al., 2007; Dwivedy et al., 2012).

For these purposes, the development of new methods and processes of drying is crucial (Correia et al., 2015). During the recent few decades, microwave drying method has taken more and more importance in drying process than conventional ones. This drying method possesses several advantages such as a raised drying rate and minimized processing energy with reducing water level (Sharma \& Prasad, 2004; Tulasidas et al., 1995).

The aim of the current investigation was to draw, on one hand, a comparison-between microwave and conventional (open-air and oven-drying) methods. On the other hand, we planned to study their effects on phenolic compounds and antioxidant activity of $L$. nobilis leaves. 


\section{Materials and methods}

\subsection{Plant material}

Samples of bay leaves, used in the drying experiments and collected from Oued-Ghir area in the Bejaia province (Algeria), were first washed by tap water and then with distilled water. After that, the leaves were wiped with an absorbent paper and stored at a lower temperature until starting the drying process.

\subsection{Air drying}

Bay leaves, dried under open-air, were placed on drying beds at a room in a single layer and raised $1.5 \mathrm{~m}$ from the ground. Psychometric conditions during the drying period for temperature and relative humidity were $12{ }^{\circ} \mathrm{C}$ to $27^{\circ} \mathrm{C}$ and $65 \%$ to $75 \%$, respectively.

\subsection{Oven drying}

Different aliquots of bay leaves (5g each) were dried in an oven (MEMMERT, Germany) using temperatures of $40,60,80,100$, and $120^{\circ} \mathrm{C}$. The oven was characterized by the interior of heating chamber with dimensions of 56 (width) x 40 (length) x $48 \mathrm{~cm}$ (height). The bay leaves were spread on a wire mesh tray and placed on top of drying chamber with an air velocity of $1.5 \mathrm{~m} / \mathrm{s}$. The variation of moisture content was measured by an analytical balance (RADWAG, Poland) correlated with sensibility fitting parameter for $0.1 \mathrm{mg}$ each $5 \min \left(60^{\circ} \mathrm{C}\right), 2 \min \left(80^{\circ} \mathrm{C}\right)$ or $1 \min \left(100^{\circ} \mathrm{C}\right.$ and $\left.120^{\circ} \mathrm{C}\right)$.

\subsection{Microwave drying kinetics}

The drying process was achieved using a microwave oven (NN-S674MF model, Samsung, Malaysia) characterized by cavity dimensions of $22.5 \mathrm{~cm}$ (width) $\times 37.5 \mathrm{~cm}$ (length) $\times 38.6 \mathrm{~cm}$ (height). The microwave was equipped with a digital control system for irradiation time and microwave power (100 to $1000 \mathrm{~W})$ and a working frequency of $2450 \mathrm{kHz}$ (Dahmoune et al., 2013).

For the drying process, $5 \mathrm{~g}$ of bay leaves were dried in the microwave using five variable microwave powers $(180,300,450,600$, and $900 \mathrm{~W})$. The mass of leaves was periodically recorded (every 5 seconds) till reaching the stability.

The results of the drying kinetics, for the three methods (open-air, oven-drying, and microwave), were expressed as a function of moisture content and reported in percentages (\%). Analyses were performed in triplicate and the initial moisture content was determined by drying in oven at $105{ }^{\circ} \mathrm{C} / 24 \mathrm{~h}$.

\subsection{Grinding and sieving of leaves}

Dried leaves, obtained from each drying process, were ground by an electrical crusher (IKA A11 basic, Germany) and collected powders were then sieved. Powder fractions with particle size $<125 \mu \mathrm{m}$ were stored in glass vials, sealed and kept in dark until needed for antioxidant extractions.

\subsection{Antioxidants extraction}

An aliquot of powder $(1 \mathrm{~g})$ was extracted using $28 \mathrm{~mL}$ of solvent $(50 \%$ ethanol). The extraction was performed by the microwave according to the protocol of Dahmoune et al. (2013). The obtained extracts were paper filtered (Whatman $n^{\circ} 1$ ) and kept at the refrigerator for further analyses. 


\subsection{Total phenolic content}

The Total Phenolic Content (TPC) was determined according to the method of Singleton \& Rossi (1965). An aliquot of extract $(500 \mu \mathrm{L})$ was mixed with $2.5 \mathrm{~mL}$ of Folin-Ciocalteau Reagent (FCR) $(10 \%)$ and $2 \mathrm{~mL}$ of sodium carbonate $(7.5 \%)$ was added after two minutes. The mixture was incubated in darkness for $15 \mathrm{~min}$ under the temperature of $50{ }^{\circ} \mathrm{C}$. The absorbance was read at $760 \mathrm{~nm}$ using a UV-Vis spectrophotometer (Spectro Scan 50, Nicosia, Cyprus). The results were expressed as mg Gallic Acid Equivalent (GAE) per g according to the calibration curve obtained by gallic acid $(y=10.80 x+0.021)$.

\subsection{Reducing power}

The extract $(0.5 \mathrm{~mL})$ was mixed with $2.5 \mathrm{~mL}$ of phosphate buffer $(0.2 \mathrm{M}, \mathrm{pH} 6.6)$ and $2.5 \mathrm{~mL}$ of $1 \%$ potassium ferricyanide. After incubating at $50{ }^{\circ} \mathrm{C}$ for $20 \mathrm{~min}$ of the obtained mixture, $2.5 \mathrm{~mL}$ of $10 \%$ trichloroacetic acid (TCA) was added. Then, $2 \mathrm{~mL}$ of the last mixture was homogenized with $2 \mathrm{~mL}$ of distilled water and finally, $0.5 \mathrm{~mL}$ of $0.1 \%$ ferric chloride was added. The absorbance of the resulting solution was measured at $700 \mathrm{~nm}$ (Pan et al., 2010). The results were expressed as mg GAE per g according to the calibration curve of gallic acid $(y=2.71 x+0.002)$.

\subsection{Statistical analysis}

Experimental results were expressed as means \pm standard deviation from triplicate analysis. The STATISTICA 5.5 software was used to compare data by Analysis of Variance (ANOVA), Least Significant Difference test (LSD test) and differences between means were considered statistically significant at $p<0.05$.

\section{Results and discussion}

\subsection{Kinetics of drying}

Drying of products guarantees water removal and better storage while preserving nutritional quality and bioactive compounds. In fact, water constitutes a key factor determining the degradation of phenolics through chemical oxidation and enzymatic action such as polyphenol oxidases that modified their structures (Tomás-Barberán \& Espín, 2001). Conventional (open-air and oven-drying) and microwave drying were adopted methods in the current study aiming to compare the performance of the two procedures.

The most common natural drying method is air drying, due to its simplest, affordable, and easily accessible means for resource-constrained households to preserve seasonal products (Maseko et al., 2019). In order to avoid drying difficulty during the cold periods, oven-drying constitutes an appropriate procedure that could retain more bioactive compounds than sun drying, reduces drying time, and improves sensory attributes such as color and texture (Mdziniso et al., 2006). The range of oven temperature variations used in the present study was from 40 to $120^{\circ} \mathrm{C}$. The use of temperatures below $40{ }^{\circ} \mathrm{C}$ leads to the approximation of the air temperature and the use of temperatures higher than $120^{\circ} \mathrm{C}$ leads to the rapid burning of the product.

Figure 1 illustrates the drying kinetics of bay leaves using open-air and oven-drying. Fresh bay leaves had low water content (57\%) comparatively to the most plant leaves used in culinary preparations such as coriander (90\%), mint (85\%), and parsley (82\%) (Alibas et al., 2019; Patil et al., 2019; Alishah et al., 2018).

The water content of the sample, dried in the open-air, gradually decreased to stabilize from the $4^{\text {th }}$ day at a value of $26.10 \%$. Drying with the oven at $40{ }^{\circ} \mathrm{C}$ allowed a faster and more effective moisture decrease of bay leaves than open-air; the water content stabilized after three days of drying at the level of $8.69 \%$. At the 
start of drying, free water was easily removed from the sample compared to the end of the process when remained water becomes bound to different plant structures, therefore it evaporates with difficulty.

The drying temperature had a significant effect on the drying kinetics of bay leaves; an increase of drying temperature reduced the time required for drying. Oven-drying using temperatures of $60^{\circ} \mathrm{C}$ to $120^{\circ} \mathrm{C}$ allowed reaching practically identical levels of moisture, but the time required was even shorter as temperature increased. The use of very high temperatures, the boiling temperature of water $\left(100^{\circ} \mathrm{C}\right)$ or higher $\left(120^{\circ} \mathrm{C}\right)$, caused an accelerated elimination of the water of bay leaves. However, recourse to temperatures below the boiling point of water showed an extension of drying kinetics.

Four days was the required time for drying under open-air. Using the oven, the time necessary to dry leaves decreased with increasing temperature, therefore, this procedure has required three days to reach the temperature of $40{ }^{\circ} \mathrm{C}$, whereas $80,48,32$, and $25 \mathrm{~min}$ were necessary to reach the temperatures of $60,80,100$, and $120^{\circ} \mathrm{C}$, respectively. These findings could agree with those of Misha et al. (2013) who found that the times necessary for using kenaf core drying were 56, 75, and $127 \mathrm{~min}$ at 55,50 , and $45{ }^{\circ} \mathrm{C}$, respectively. Concerning coriander leaves, Hihat et al. (2017) used the oven at the same temperatures as in our study, found that moisture loss had also a proportional relationship with temperature increase and inversely proportional to the time required for drying.

The final water content of the bay leaves depended on the temperature used for drying; in other words, it was higher when the temperature was lower. Indeed, the drying in open-air (about $23^{\circ} \mathrm{C}$ ) produced bay leaves with a water content of $26.01 \%$, while the use of high temperatures $\left(80^{\circ} \mathrm{C}\right.$ to $\left.120{ }^{\circ} \mathrm{C}\right)$ allowed reducing moisture content to a very low level (about 5\%).
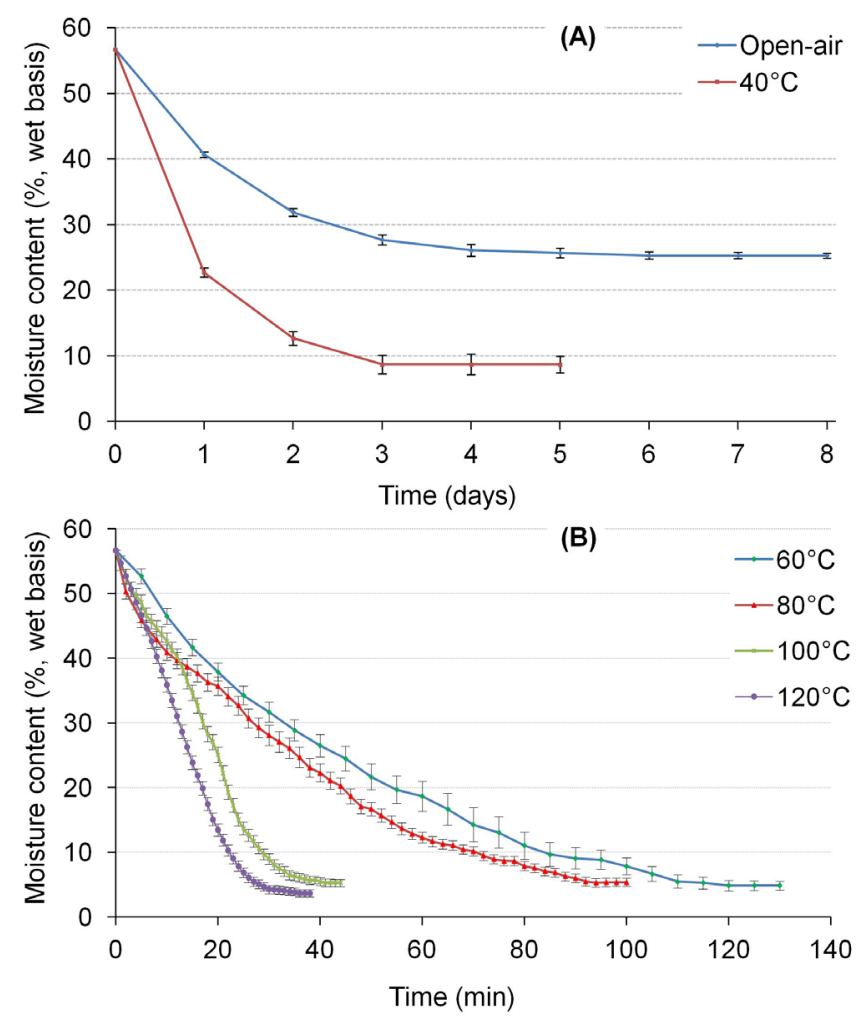

Figure 1. Comparison between open-air and oven at $40^{\circ} \mathrm{C}(\mathrm{A})$ and oven at $60^{\circ} \mathrm{C}$ to $12^{\circ} \mathrm{C}$ (B) drying kinetics of Laurus nobilis leaves. 


\subsection{Microwave-assisted drying kinetics}

Drying curves obtained by different microwave powers are presented in Figure 2. Drying kinetics of L. nobilis leaves showed that moisture content decreased rapidly at the start of the microwave drying process and further, it gradually decreased until the end of the drying. The statistical analysis revealed that in the exception of $180 \mathrm{~W}$, all other microwave powers $(300$ to $900 \mathrm{~W})$ displayed the same drying efficiency. Indeed, the moisture content of bay leaves dried using the power of $180 \mathrm{~W}$ was stabilized at $20.49 \%$ after 170s. It was important to note that the drying with the microwave powers from 300 to $900 \mathrm{~W}$ showed a stabilization after $130 \mathrm{~s}$ at an average moisture level of $9.1 \%$. According to the obtained results, it could be observed that the drying rate of bay leaves remained practically the same if a certain energy threshold was reached. The obtained results were not completely in accordance with those found by Kumar et al. (2014) who showed that the time required to achieve moisture equilibrium $(6 \%)$ of ginger slices decreased when the microwave power increases. It should be mentioned that $300 \mathrm{~W}$ was the most appropriate power for drying bay leaves, since it was similar to higher powers $(450$ to $900 \mathrm{~W})$, in terms of time and drying efficiency and with less energy consumption. The results obtained in the present investigation showed that, as compared to conventional method, the drying time required to achieve equilibrium moisture content can be significantly shortened by microwave.

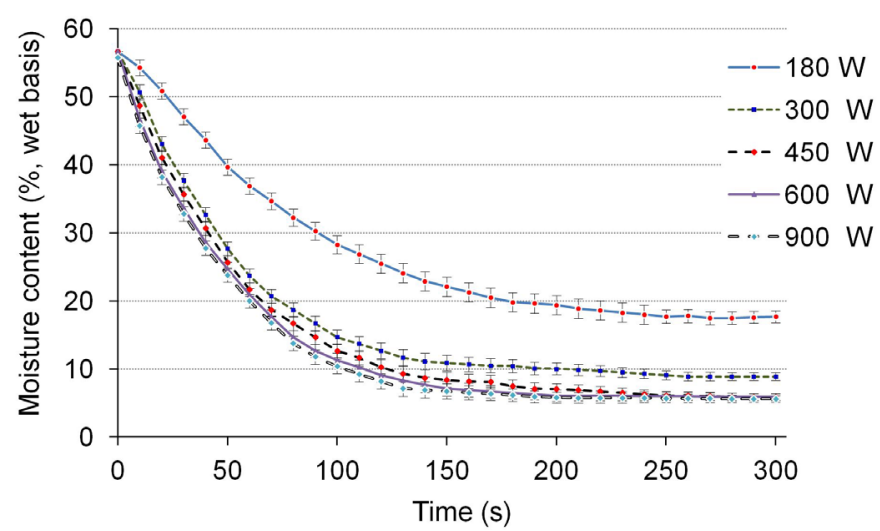

Figure 2. Microwave drying kinetics of Laurus nobilis leaves.

The use of low temperatures (as in the case of open-air) and microwave power (e.g. $180 \mathrm{~W}$ ) were not effective for drying due to low energy. So, for suitable drying, a certain energy threshold must be exceeded to evaporate the water of the bay leaves. On the one hand, this energy must be sufficient to oppose the hygroscopic effect exerted by the constituents of the product, especially sugars, on water molecules and; on the other hand, the surrounding humidity. Therefore, the increase of the temperature power of drying caused the reduction of relative humidity thus increased water evaporation (Misha et al., 2013).

The principle used for microwave drying was different from drying by a heat source. During conventional drying, the heat was transferred to the surface of the material by conduction, convection, and/or radiation, and driving into the interior by thermal conduction. For microwave drying, the microwaves penetrate the material and interact with water that is a polar molecule. As water molecules are dipolar in nature, they rotate following the electric field that alternates at very high frequency. Such rotation produces friction of molecules and generates heat inside the material. Seeing that foods are water-rich, microwaves can generate significant volumetric heat. Heated water increase diffusion rate and pressure gradient that facilitates to drive off moisture from inside to outside of the material.

The advantages of microwave drying, when compared with convective drying, were a reduction in the drying time of up to $25 \%$ to $90 \%$ and an increase in drying rate of 4 to 8 times. The efficiency of microwave drying is due to the fact that the energy directly interacts with water molecules, that eliminates the need to transfer heat 
from the surface into the interior of the product, inducing the increase of driving force for moisture transfer due to the generation of elevated internal vapor pressure directed to the external (Feng et al., 2012).

\subsection{Total phenolic content}

The TPC of L. nobilis leaves, obtained by different drying methods (open-air, oven-drying, and microwave), are illustrated in Figure 3. For conventional drying, phenolic concentrations varied from one temperature to another and oscillated from 38 to $51 \mathrm{mg} \mathrm{GAE} / \mathrm{g}$; drying in open-air and oven-drying using $120^{\circ} \mathrm{C}$ could achieve the highest levels of TPC. The different fluctuations on TPC may be due to the variation of the used temperature in relation to the time required to drying. Indeed, the increase in the drying temperature can reduce the time of exposure to heat due to the quick drying of leaves but, on the other hand, it also promotes the degradation of the bioactive compounds.

From TPC results obtained by microwave drying, it was noticed that the lower phenolic content was obtained by the power of $180 \mathrm{~W}$. The rise of the power to $300 \mathrm{~W}$ leads to an increase in TPC to reach the highest level then decreased for the highest powers. The increase of TPC for $300 \mathrm{~W}$ can be due to the increase of vapor pressure and temperature generated by microwaves that could break cell walls allowing the release of phenolic compounds that become more accessible during the extraction (Dong et al., 2019). However, the use of powers from 450 to $900 \mathrm{~W}$ leads to a significant TPC diminution that can be related to the degradation of these bioactive compounds by high temperatures generated by elevated microwave levels. The concentration of polyphenols declined during drying, and the behavior may be attributed to the chemical degradation, the formation of insoluble oxidation compound, the production of polymers, and the decomposition of thermolabile compounds (Obied et al., 2008; Henríquez et al., 2014). The obtained results were in line with those of Saha et al. (2019) who found that the drying of corncob by microwave using $130 \mathrm{~W}$ provided the highest TPC; while drying with 600 and $900 \mathrm{~W}$ caused the diminution of phenolic compounds and antioxidant activity.
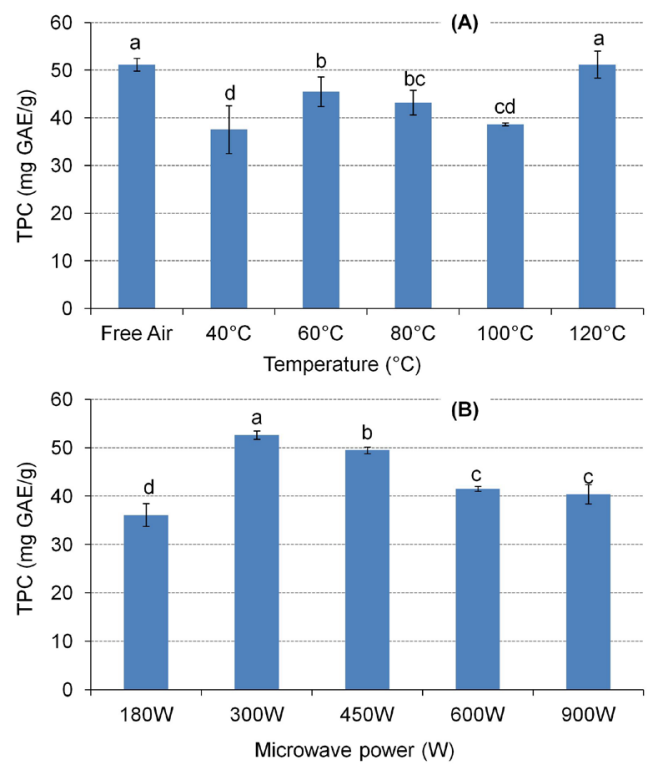

Figure 3. Effect of conventional (A) and microwave (B) drying on total phenolic content of Laurus nobilis leaves. Results with different letters for conventional or microwave drying method are significantly different at $p<0.05$, with $a>b>c>d$. 


\subsection{Antioxidant activity}

The results of conventional drying showed that the highest antioxidant activity was obtained by the leaves dried at open-air followed by those at $120^{\circ} \mathrm{C}$ and the others provided significantly lower activities (Figure 4). The antioxidant activity profile followed the same pattern as TPC. Open-air drying allowed better preservation of bay leaves antioxidants. Oven-drying $\left(40{ }^{\circ} \mathrm{C}\right.$ to $\left.100^{\circ} \mathrm{C}\right)$ induced a significant reduction of these bioactive compounds, indicating the presence of thermolabile phenolic compounds.

The increase in phenol content and antioxidant activity, observed for dried leaves at $120^{\circ} \mathrm{C}$, might be due to the formation of the browning compounds rather than to the bioactive ones. This is supported by several studies that have found that Maillard compounds, produced during heating, can interfere during phenolic compounds determination and antioxidant activity evaluation (Pérez-Burillo et al., 2019; Mondaca-Navarro et al., 2017).

Concerning microwave drying, it was noticed that the power of $300 \mathrm{~W}$ provided a better antioxidant activity followed by $450 \mathrm{~W}$. Antioxidant activity manifested by the dried leaves with a microwave followed the same pattern as phenolic compounds.

Statistical analysis indicated a very highly significant value $(p<0.001)$ of Pearson correlation coefficient $(r=0.83)$ between phenolic contents and antioxidant activity of dried bay leaves obtained by different drying methods. This indicated that phenolic compounds of $L$. nobilis leaves were responsible for $83 \%$ of its antioxidant activity. These findings are in line with those of several researchers (Izli et al., 2017; Bachir bey et al., 2014).
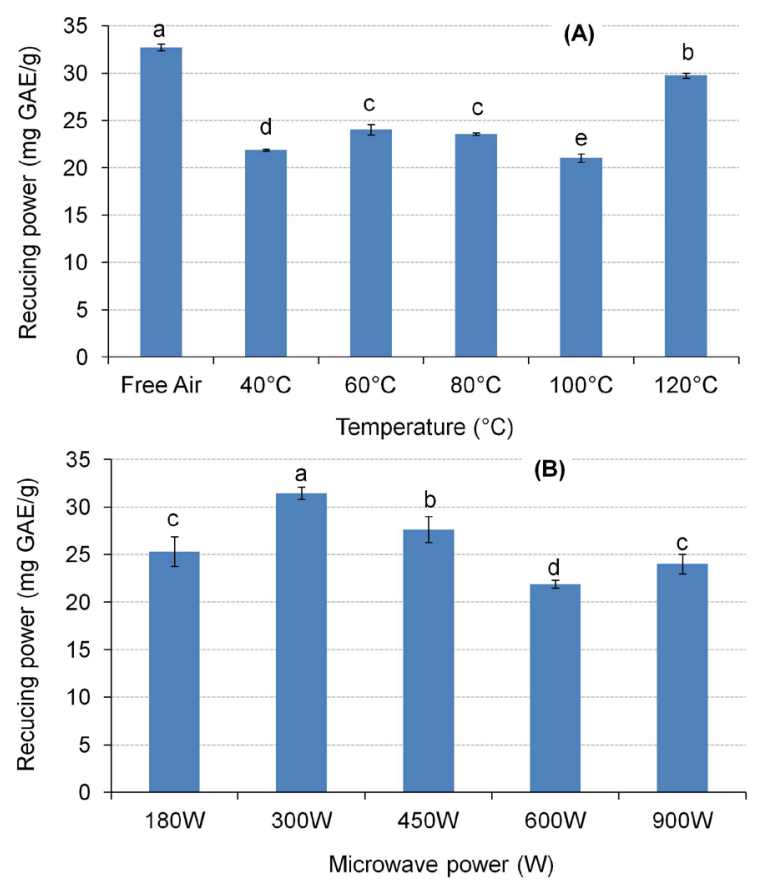

Figure 4. Effect of conventional (A) and microwave (B) drying on antioxidant activity of Laurus nobilis leaves. Results with different letters for conventional or microwave drying method are significantly different at $p<0.05$, with $a>b>c>d>e$.

\section{Conclusion}

According to the obtained results, it could be noticed that bay leaves dried in open-air $\left(23^{\circ} \mathrm{C}\right)$ and with oven-drying using low temperatures $\left(40{ }^{\circ} \mathrm{C}\right)$ took a prolonged time to moisture stabilization ( 3 or 4 days). The required time of drying to achieve moisture equilibrium was reduced by using high temperatures and 
mostly shortened by the microwave drying. It is stated that L. nobilis leaves dried in the open-air (4 days) and microwave $(300 \mathrm{~W} / 130 \mathrm{~s})$ displayed the highest TPC and antioxidant activity. Thus, taking account of drying time and antioxidant parameters, we could consider that the microwave-assisted method using a power of $300 \mathrm{~W}$ during $130 \mathrm{~s}$ was selected to produce better dried bay leaves.

\section{Acknowledgements}

Authors thank the "Ministère Algérien de l'Enseignement Supérieur et de la Recherche Scientifique" and express their gratitude to Pr. Meghit Boumediene KHALED for final revision and edition of the article.

\section{References}

Alibas, I., Zia, M. P., \& Yilmaz, A. (2019). The effect of drying methods on color and chlorophyll content of parsley leaves. Turkish Journal of Agriculture-Food Science and Technology, 7(6), 919-926.

Alishah, A., Kiamahalleh, M. V., Yousefi, F., Emami, A., \& Kiamahalleh, M. V. (2018). Solar-assisted heat pump drying of coriander: an experimental investigation. International Journal of Air-Conditioning and Refrigeration, 26(4), 1-13. http://dx.doi.org/10.1142/S2010132518500372

Bachir bey, M., Louaileche, H., \& Mouhoubi, Z. (2014). Antioxidant activity of eight tomato (Lycopersicon esculentum L.) varieties grown in Algeria. Journal of Food Technology Research, 1(2), 133-145.

Batool, S., Khera, R. A., Hanif, M. A., \& Ayub, M. A. (2020). Bay leaf. In M. A. Hanif, M. M. Khan, H. Nawaz, \& H. J. Byrne (Eds.), medicinal plants of South Asia (pp. 63-74). Netherlands: Elsevier. http://dx.doi.org/10.1016/B978-0-08-102659-5.00005-7.

Caputo, L., Nazzaro, F., Souza, L. F., Aliberti, L., De Martino, L., Fratianni, F., Coppola, R., \& De Feo, V. (2017). Laurus nobilis: composition of essential oil and its biological activities. Molecules, 22(6), 930. PMid:28587201.

http://dx.doi.org/10.3390/molecules22060930

Chahal, K. K., Kaur, M., Bhardwaj, U., Singla, N., \& Kaur, A. (2017). A review on chemistry and biological activities of Laurus nobilis L. essential oil. Journal of Pharmacognosy and Phytochemistr, 6(4), 1153-1161.

Correia, A., Loro, A., Zanatta, S., Spoto, M., \& Vieira, T. (2015). Effect of temperature, time, and material thickness on the dehydration process of tomato. International Journal of Food Sciences, 2015, 1-7. PMid:26904666. http://dx.doi.org/10.1155/2015/970724

Dahmoune, F., Boulekbache, L., Moussi, K., Aoun, O., Spigno, G., \& Madani, K. (2013). Valorization of Citrus limon residues for the recovery of antioxidants: evaluation and optimization of microwave and ultrasound application to solvent extraction. Industrial Crops and Products, 50, 77-87. http://dx.doi.org/10.1016/j.indcrop.2013.07.013

Di Scala, K., \& Crapiste, G. (2008). Drying kinetics and quality changes during drying of red pepper. Lebensmittel-Wissenschaft + Technologie, 41(5), 789-795. http://dx.doi.org/10.1016/j.lwt.2007.06.007

Dong, Q., He, D., Ni, X., Zhou, H., \& Yang, H. (2019). Comparative study on phenolic compounds, triterpenoids, and antioxidant activity of Ganoderma lucidum affected by different drying methods. Journal of Food Measurement and Characterization, 13(4), 1-8. http://dx.doi.org/10.1007/s11694-019-00242-0

Dwivedy, S., Rayaguru, K., \& Sahoo, G. (2012). Effect of drying methods on quality characteristics of medicinal indian borage (Coleus aromaticus) leaves. Journal of Food Processing \& Technology, 3(11), 1-6. http://dx.doi.org/10.4172/21577110.1000188

Feng, H., Yin, Y., \& Tang, J. (2012). Microwave drying of food and agricultural materials: basics and heat and mass transfer modeling. Food Engineering Reviews, 4(2), 89-106. http://dx.doi.org/10.1007/s12393-012-9048-x

Fidan, H., Stefanova, G., Kostova, I., Stankov, S., Damyanova, S., Stoyanova, A., \& Zheljazkov, V. D. (2019). chemical composition and antimicrobial activity of Laurus nobilis L. essential oils from Bulgaria. Molecules (Basel, Switzerland), 24(4), 804. PMid:30813368. http://dx.doi.org/10.3390/molecules24040804

Henríquez, C., Córdova, A., Almonacid, S., \& Saavedra, J. (2014). Kinetic modeling of phenolic compound degradation during drum-drying of apple peel by-products. Journal of Food Engineering, 143, 146-153. http://dx.doi.org/10.1016/j.jfoodeng.2014.06.037

Hihat, S., Remini, H., \& Madani, K. (2017). Effect of oven and microwave drying on phenolic compounds and antioxidant capacity of coriander leaves. International Food Research Journal, 24(2), 503-509.

Izli, N., Izli, G., \& Taskin, O. (2017). Drying kinetics, colour, total phenolic content and antioxidant capacity properties of kiwi dried by different methods. Journal of Food Measurement and Characterization, 11(1), 64-74. http://dx.doi.org/10.1007/s11694016-9372-6

Kumar, A., Kulkarni, N., \& Kedarnath, M. (2014). Mathematical Modeling of Microwave drying kinetics of Ginger (Zingiber officinale) slices. Journal of Postharvest Technology, 2(1), 88-95.

Li, Z., Raghavan, G., \& Orsat, V. (2010). Temperature and power control in microwave drying. Journal of Food Engineering, 97(4), 478-483. http://dx.doi.org/10.1016/j.jfoodeng.2009.11.004 
Conventional method and microwave drying kinetics of Laurus nobilis leaves: effects on phenolic compounds and antioxidant activity

Khaled Khodja, Y. et al.

Maroulis, Z. B., \& Saravacos, G. D. (2003). Food process design (Vol. 126). Boca Raton: CRC Press. http://dx.doi.org/10.1201/9780203912010.

Maseko, I., Mabhaudhi, T., Ncube, B., Tesfay, S., Araya, H. T., Fessehazion, M. K., Chimonyo, V. G. P., Ndhlala, A. R., \& Du Plooy, C. P. (2019). Postharvest drying maintains phenolic, flavonoid and gallotannin content of some cultivated African leafy vegetables. Scientia Horticulturae, 255, 70-76. http://dx.doi.org/10.1016/j.scienta.2019.05.019

Mdziniso, P., Hinds, M. J., Bellmer, D. D., Brown, B., \& Payton, M. E. (2006). Physical quality and carotene content of solardried green leafy and yellow succulent vegetables. Plant Foods for Human Nutrition (Dordrecht, Netherlands), 61(1), 12-20. PMid:16683189. http://dx.doi.org/10.1007/s11130-006-0003-y

Misha, S., Mat, A. S., Ruslan, M. H., Sopian, K., \& Salleh, E. (2013). The effect of drying air temperature and humidity on the drying kinetic of kenaf core. Applied Mechanics and Materials, 315, 710-714.

http://dx.doi.org/10.4028/www.scientific.net/AMM.315.710

Mondaca-Navarro, B. A., Ávila-Villa, L. A., González-Córdova, A. F., López-Cervantes, J., Sánchez-Machado, D. I., CampasBaypoli, O. N., \& Rodríguez-Ramírez, R. (2017). Antioxidant and chelating capacity of Maillard reaction products in amino acidsugar model systems: applications for food processing. Journal of the Science of Food and Agriculture, 97(11), 3522-3529. PMid:28071805. http://dx.doi.org/10.1002/jsfa.8206

Obied, H. K., Bedgood Jr, D. R., Prenzler, P. D., \& Robards, K. (2008). Effect of processing conditions, prestorage treatment, and storage conditions on the phenol content and antioxidant activity of olive mill waste. Journal of Agricultural and Food Chemistry, 56(11), 3925-3932. PMid:18457398. http://dx.doi.org/10.1021/jf703756d

Ozkan, I. A., Akbudak, B., \& Akbudak, N. (2007). Microwave drying characteristics of spinach. Journal of Food Engineering, 78(2), 577-583. http://dx.doi.org/10.1016/j.jfoodeng.2005.10.026

Pan, Y., He, C., Wang, H., Ji, X., Wang, K., \& Liu, P. (2010). Antioxidant activity of microwave-assisted extract of Buddleia officinalis and its major active component. Food Chemistry, 121(2), 497-502. http://dx.doi.org/10.1016/j.foodchem.2009.12.072

Patil, M. D. R., Kore, M. S. S., Patil, M. V. N., Mane-Deshmukh, M. A. S., Mali, S. B., \& Durgade, D. P. (2019). Artificial lightning in solar tunnel dryer for coriander. International Research Journal of Engineering and Technology, 6(7), 1051-1056.

Pérez-Burillo, S., Rufián-Henares, J. Á., \& Pastoriza, S. (2019). Effect of home cooking on the antioxidant capacity of vegetables: relationship with Maillard reaction indicators. Food Research International, 121, 514-523. PMid:31108776. http://dx.doi.org/10.1016/j.foodres.2018.12.007

Saha, S. K., Dey, S., \& Chakraborty, R. (2019). Effect of microwave power on drying kinetics, structure, color, and antioxidant activities of corncob. Journal of Food Process Engineering, 42(4), 13021. http://dx.doi.org/10.1111/jfpe.13021

Sharma, G., \& Prasad, S. (2004). Effective moisture diffusivity of garlic cloves undergoing microwave-convective drying. Journal of Food Engineering, 65(4), 609-617. http://dx.doi.org/10.1016/j.jfoodeng.2004.02.027

Singleton, V. L., \& Rossi, J. A. (1965). Colorimetry of total phenolics with phosphomolybdic-phosphotungstic acid reagents. American Journal of Enology and Viticulture, 16(3), 144-158.

Tomás-Barberán, F. A., \& Espín, J. C. (2001). Phenolic compounds and related enzymes as determinants of quality in fruits and vegetables. Journal of the Science of Food and Agriculture, 81(9), 853-876. http://dx.doi.org/10.1002/jsfa.885

Tulasidas, T., Raghavan, G., \& Mujumdar, A. (1995). Microwave drying of grapes in a single mode Cavity at 2450 Mhz-11: Quality and energy aspects. Drying Technology, 13(8-9), 1973-1992. http://dx.doi.org/10.1080/07373939508917059. 